WEISS, J. Beiträge zur paulinischen Rhetorik. In: Theologiche Studien: Bernhard Weiss zu seinem 70 Geburststage. Göttingen: Vandenhoeck \& Ruprecht, 1897, p. 165-247.

ZERWICK, M. Biblical Greek. Roma: Pontificio Istituto Biblico, 1994.

Recebido em: 11/10/2016

Aprovado em: 15/05/2017

\section{A "opção preferencial pelos pobres" como chave hermenêutica da Exortação Apostólica Evangelii Gaudium}

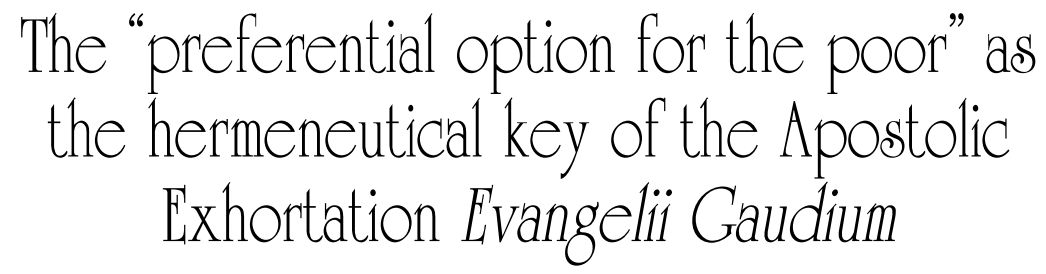

Vitor Hugo Lourenço*

Resumo: A opção preferencial pelos pobres é uma das marcas mais singulares da Igreja latino-america. Cunhada a partir do Concílio Vaticano II e tendo seu ápice nas Conferências de nosso Episcopado, especialmente Medellín, ela encontra eco novamente no pontificado de Francisco, que tem se revelado sensível às questões sociais. Partindo deste princípio, o presente artigo busca analisar a opção supracitada como uma chave hermenêutica de sua Exortação Apostólica Evangelii Gaudium. Para este propósito, tem-se como ponto de partida a compreensão da tarefa hermenêutica da teologia, passando pela força do impulso conciliar, o florescimento de uma nova tradição, o conceito de opção pelos pobres e contra a pobreza, culminando nas reflexões de Francisco a partir de sua exortação e nos seus desdobramentos para a vida da Igreja como um todo.

Palavras-chave: Hermenêutica. Opção. Pobres. Vaticano II. América Latina. Papa Francisco.

* Sacerdote católico, religioso passionista, doutorando em Teologia pela Pontifícia Universidade Católica do Paraná - PUCPR - Curitiba-PR. E-mail: vitorhugocp@hotmail.com. 
Abstract: The preferential option for the poor is one of the most unique brands of the Latin American Church. Coined from the Second Vatican Council and having its culmination in the Conferences of our Episcopate, especially Medellin, it echoes again in the pontificate of Francis who has been sensitive to social issues. Starting from this principle, the present article seeks to analyze the aforementioned option as a hermeneutical key of its Apostolic Exhortation Evangelii Gaudium. For this purpose the starting point is the understanding of the hermeneutical task of theology, passing through the force of the conciliar impulse, the flourishing of a new tradition, the concept of option for the poor and against poverty, culminating in the reflections of Francisco from of its exhortation and its unfolding for the life of the Church as a whole.

Keywords: Hermeneutics. Option. Poor. Vatican II. Latin America. Pope Francis.

\section{Introdução}

Desde os primórdios do cristianismo sempre existiu uma profunda preocupação com os pobres e marginalizados. As primeiras comunidades cristãs fundadas ainda pelos apóstolos encontravam na caridade uma forma concreta de viver o Evangelho e seguir o exemplo de Jesus. Com o passar do tempo e a institucionalização da Igreja aos poucos o cuidado pastoral para com os mais necessitados foi sendo relativizado em vista do desejo de expansão do cristianismo por toda extensão do Império Romano, por uma preocupação cada vez mais exacerbada com os dogmas e as doutrinas, com a defesa da fé frente aqueles que faziam oposição à nova religião imperial.

Paralelo ao desenvolvimento do cristianismo, a teologia durante muito tempo, se ateve a uma postura apologética e de profunda submissão institucional, salvo algumas exceções, obstruindo assim, de modo geral, a sua capacidade hermenêutica de ver no mundo e nos acontecimentos históricos sinais da revelação divina. Fechada cada vez mais em si, a Igreja experimentou um novo tempo com a convocação do Concílio Vaticano II. João XXIII, coloca uma vez mais a Igreja em sintonia com o mundo e com a história, fazendo destes, um espaço, um "lugar teológico", interpretando à luz da Palavra os desafios do tempo presente, como o florescimento das injustiças sociais, o êxodo rural, o fenômeno da pobreza nos centros urbanos a necessidade de diálogo com o mundo, com todos os cristãos e não cristãos, abrindo precedente para que as Conferências Episcopais pudessem pensar a sua própria caminhada, fazer as suas próprias escolhas, eleger as suas próprias prioridades em vista de uma nova evangelização.

O pontificado de Francisco reabilita a opção preferencial pelos pobres que ele como teólogo e pastoralista latino-americano ajudou a construir e hoje por meio de sua Exortação Apostólica Evangelii Gaudium (2013) eleva essa discussão ao Magistério Universal da Igreja. Lançando o olhar sobre esta opção, especialmente a partir das intuições do Concílio Vaticano II e sua recepção no CELAM, nosso objetivo é analisar a forma que ela pode ser entendida como uma chave hermenêutica da primeira exortação apostólica de um papa latino-americano, e quais as suas principais ressonâncias em nosso contexto eclesial, teológico e pastoral. Naturalmente, não temos a pretensão de esgotar essa discussão, mas nos debruçar uma vez mais sobre a temática em sua relevância, especialmente neste tempo de abertura em que a Igreja é chamada a "sair" em direção às “periferias”, a ser solidária com os pobres e marginalizados, movida pelos sentimentos de compaixão e misericórdia.

\section{A tarefa hermenêutica da teologia}

Ao refletirmos sobre a realidade, no momento histórico em que estamos vivendo, podemos constatar grandes e profundas mudanças na sociedade. ${ }^{1}$ Valores e costumes que nortearam a vida e as

Cf. BRIGHENTI, A. A Igreja perplexa: a novas perguntas, novas respostas, p. 9ss. 
relações sociais durante um longo período, não respondem mais de modo efetivo aos anseios e desafios do tempo presente, marcado especialmente, por uma mudança de época, pela formulação de novos paradigmas, novas maneiras de viver e pensar, novas cosmovisões e cosmogonias.

A teologia, esforço humano de compreender o ser de Deus a partir de sua revelação no tempo e na história, é desafiada uma vez mais a partir do novo que se descortina, reinterpretar, compreender e atualizar a mensagem cristã, a ética que ela traz em si, sua forma de ser assimilada, sua apropriação por parte das pessoas, das culturas e dos povos, sem perder é claro a sua essência, sua transculturalidade e transtemporalidade.

Em sua tarefa hermenêutica, a teologia se propõe reelaborar a compreensão do ser cristão e sua especificidade no mundo enquanto agente capaz de viver e transformar o mundo segundo os valores e a ética contidos no Evangelho. Diante de novas questões, de novos desafios, o teólogo é alguém que deve apontar para uma necessária reflexão sobre o mistério e o mistério da vida, sobre o sentido $^{2}$ que a ela se dá, sua relação e intimidade com Deus e com o outro. A sociedade e o mundo não são estáticos, são dinâmicos. Nesta perspectiva, o novo deve ser acolhido como práxis que amplia a compreensão do mistério, um autêntico lugar teológico, que oferece uma nova condição, um novo pensar.

A teologia como ciência hermenêutica visa tematizar a "reinterpretação dos acontecimentos fundadores”, à luz do que se chamou na Tradição cristã de Revelação, como dado da fé, enquanto significado da vida das comunidades de fiéis e como prática significante, que continua a iluminar a tarefa de interpretação que torna a Tradição viva, em sua dinâmica de continuar renovando o sentido da mensagem cristã.

2 Cf. BOFF, C. O livro do sentido: crise e busca de sentido hoje (parte crítico-analítica), vol. 1. p. 11-62.
A teologia em sua essência sempre foi hermenêutica da fé. Faz parte de seu próprio conceito, identidade e estatuto ontológico. Reinterpreta e organiza os dados revelados, vividos e compreendidos na e pela comunidade eclesial, em diferentes contextos e realidades socioculturais e históricos. Caso não exerça essa missão, as formulações de fé se tornam anacrônicas, reduzindo-se, com o tempo, à “recitação de fórmulas de pouca ou insignificante inteligibilidade”. ${ }^{3}$

Se a tarefa hermenêutica sempre existiu, a consciência de sua utilização é relativamente nova. No esquema mental vigente até o advento da modernidade, pensava-se que o conhecer visava a alcançar de forma definitiva o sentido único do texto. A verdade estava já fixada. Bastava ter acesso a ela, desobstruindo o olhar. Daí a concepção clássica de que a verdade é a adequação da mente com o objeto.

Neste contexto, até a palavra “interpretação” soava como estranha, parecia desnecessária. Numa visão “a-histórica”, o problema hermenêutico é bastante simplificado: as verdades abstratas, eternas, possuem formulações definitivas. Como as coordenadas culturais de tempo e espaço não são conscientemente levadas em consideração na formulação dos dados da fé, não se pensa em reformulá-los, quando estas coordenadas se modificam. As mudanças históricas, na organização da sociedade ou do pensamento, são interpretadas como desvios da ordem cristã. Não podem, por isso, constituir fator de auxílio para a elaboração teológica. A “teologia perene” responde às questões centrais da fé. As formulações necessitam somente ser entendidas ou adaptadas, mas não reelaboradas. ${ }^{4}$

Várias fontes levam a perceber a necessidade da hermenêutica: a descoberta da historicidade, a revalorização das culturas, o reconhecimento do sujeito cognoscente, a percepção do conflito social e a semiótica. A consciência da historicidade e a compreensão do

LIBANIO, J.B; MURAD, A. Introdução à teologia: perfil, enfoques, tarefas, p. 336 $4 \quad$ Ibidem, p. 337. 
processo de conhecimento, no correr da história da humanidade, fazem ver que a verdade não é inteiramente preexistente e objetiva. Já não se considera o cristianismo como um depósito ou sistema objetivo de verdades prévias à realidade histórica. A verdade é bus$\mathrm{ca}$, dependente de sua historicidade concreta, fundamentalmente processual e contextualizada, sem deixar de ter valor universal; do contrário só existe como abstração conceitual. ${ }^{5}$

A hermenêutica teológica, porém, mais do que hermenêutica bíblica, é uma hermenêutica da fé cristã e de sua práxis de vida. A teologia hermenêutica, no sentido amplo da palavra, é a práxis interpretativa de uma representação soteriológica da realidade, cuja necessidade de redenção articula essa à luz da realidade salvífica do testemunho bíblico. ${ }^{6}$

A teologia latino-americana tematiza de forma ímpar a inter-relação entre reflexão sistemática e ótica interpretativa à luz do clássico axioma: "o lugar social condiciona o lugar hermenêutico". O teólogo, especialmente mergulhado em nosso contexto, social e político, próximo do mundo dos pobres, ouvindo seus clamores e sentindo a interpelação ética que surge de sua situação, vê o rosto de Deus no "reverso da história". Faz a si mesmo perguntas que seu colega "de escritório" jamais pensou. "Encontra sinais de Deus onde parecia não haver nada. Busca saídas concretas para a situação, pois o gemido do sofrimento do povo não se apazigua com livros escritos, nem se silencia por detrás de estantes de bibliotecas". ${ }^{7}$

A postura hermenêutica da teologia se desdobra da agenda teológica do Concílio Vaticano II, ao apresentar que "uma coisa é o próprio depósito de fé ou as verdades e outra é o modo de enunciá-las, de relacioná-las com a vida, especialmente dos mais sofredores, com

\footnotetext{
5 Ibidem.

6 Cf. KÖRTNER, Ulrich H. J. Introdução à hermenêutica teológica.

LIBANIO, J.B; MURAD, A. op. cit., p. 338.
}

a história, que está em curso, com o tempo e as culturas, conservando-se, contudo, o mesmo sentido e significado". ${ }^{8}$

\section{0 impulso conciliar}

O Concílio Vaticano II (1962-1965) representou e continua representando um novo tempo na vida da Igreja. Fechada durante muito tempo em uma visão estreita de mundo, ela viu ruir parte de suas estruturas, de sua significância para a sociedade e para vida das pessoas. A "primavera conciliar", o "amanhecer de um novo dia" na vida Igreja, a colocou na "ordem do dia", sintonizando-a com a humanidade, com tudo aquilo que a compõe, sendo sinal de Cristo "luz dos povos" em perspectiva "ecumênica" com todos os cristãos, em atitude de "diálogo" com o mundo, com as demais confissões religiosas, redescobrindo assim, sua vocação "sacramental” e acima de tudo, "missionária", profética e evangelizadora. ${ }^{9}$

Sobre o desejo de uma Igreja, mais próxima e capaz de interpretar os desafios do homem hodierno e de suas lutas cotidianas, frisa um dos mais importantes documentos conciliares:

As alegrias e as esperanças, as tristezas e as angústias dos homens de hoje, sobretudo dos pobres e de todos aqueles que sofrem, são também as alegrias e as esperanças, as tristezas e as angústias dos discípulos de Cristo; e não há realidade alguma verdadeiramente humana que não encontre eco no seu coração. ${ }^{10}$

O “Papa bom”, como era conhecido João XXIII, sentia que a Igreja precisava recordar a intuição, a vivência, a caridade e o profetismo das primeiras comunidades cristãs (fontes bíblicas e patrísticas). Por meio de uma mensagem, faltando exatamente um mês para o início do Concílio, manifesta a convicção de que um "novo mundo"

$8 \quad G S 62$.

$9 \quad L G 1, U R 6, N A 2, A G 5$.

10 GS 1 . 
e uma "nova Igreja” são possíveis. Conclama a todos a edificarem a Igreja como "Igreja dos pobres”, a Igreja “povo de Deus”, destaca:

Para os países em desenvolvimento a Igreja é apresentada como é e como ela quer ser, como Igreja de todos, especialmente como a Igreja dos pobres. Haverá que gritar e lamentar uma vez mais a cada nova ofensa e violacão do quinto e do sétimo mandamento do sagrado Decálogo: o não fazer caso dos compromissos que se seguem do sétimo mandamento: as misérias da vida social, que pedem vingança na presença de Deus: é dever de todo homem, e dever mais urgente para o cristão, considerar o supérfluo com a medida das necessidades do próximo e cuidar bem para que na administração e distribuição dos bens criados seja feita em benefício de todos ${ }^{11}$

Reafirmando a compreensão hermenêutica de que Deus se revela na história, na vida, especialmente onde ela se encontra mais ameaçada, e em defesa de uma Igreja "pobre" e "para os pobres", o Cardeal Lercaro, figura singular ao longo das seções conciliares, com grande lucidez e visão de futuro, afirmou que: "não respondemos às verdadeiras e mais profundas exigências de nosso tempo (incluindo nossa esperança de favorecer a unidade dos cristãos), e mais propriamente fugiríamos delas se tratássemos o tema da evangelização dos pobres como um dos numerosos temas do Concílio". Enfatizou: "o tema do Concílio é a Igreja, sobretudo como Igreja dos pobres". ${ }^{12}$

Retomando o conceito de "mistério de Cristo", cunhado por Lercaro, ${ }^{13}$ Gutiérrez nos recorda que o tema dos pobres além de seu aspecto social deve ser pensado em uma perspectiva teológica. Situar o mistério e o ministério de Cristo no âmago do assunto. A ausência de uma maior compreensão hermenêutica de um Cristo solidário com os pobres (aspecto essencial da mensagem cristã), associando

1 JOÃO XXIII. Radiomensaje de su santidad Juan XXIII un mes antes de la apertura del Concilio Vaticano II (Martes 11 de septiembre de 1962).

12 LERCARO, G. Per la forza dello Spirito: Discorsi conciliari, p. 109 ss

13 Ibidem, p. 114 ao mesmo tempo elementos sociais e teológicos, pode ser considerada como uma das grandes lacunas dos esquemas preparatórios do Concílio. Para o teólogo da libertação, “a situação dos pobres não só deve ser considerada em relação com os ensinamentos sociais, mas, sobretudo à luz de Cristo e de seu Reino. Nessa perspectiva, não é de se estranhar que o arcebispo de Bologna considerasse que pôr no cerne do Concílio o tema da Igreja dos pobres era uma exigência”. ${ }^{14}$

Apesar de não termos tido no Concílio o aprofundamento que necessitara a "Igreja dos pobres”, a fala de João XXIII aponta para um viés que até então era pouco debatido: o de uma Igreja que deve assumir em si a perspectiva dos que estão à margem do mundo. Fruto de seu esforço pessoal e de sua capacidade de articulação, sobre o cuidado e a defesa da dignidade humana, vão afirmar os padres conciliares:

Simultaneamente, aumenta a consciência da eminente dignidade da pessoa humana, por ser superiora a todas as coisas e os seus direitos e deveres serem universais e invioláveis. É necessário, portanto, tornar acessíveis ao homem todas as coisas de que necessita para levar uma vida verdadeiramente humana: alimento, vestuário, casa, direito de escolher livremente o estado de vida e de constituir família, direito à educação, ao trabalho, à boa fama, ao respeito, à conveniente informação, direito de agir segundo as normas da própria consciência, direito à proteção da sua vida e à justa liberdade mesmo em matéria religiosa. ${ }^{15}$

Influenciado pela reflexão proposta pelo Concílio, Gutiérrez argumenta que a situação dos pobres que vivem hoje num mundo em que as estruturas injustas forçam a maior parte da família humana a viver em condições desumanas deveria ser uma constante lembrança para nós de que Deus optou pelos pobres, segundo o desígnio salvífico revelado em Jesus Cristo que “veio proclamar a Boa Notícia

14 GUTIÉRREZ, G. A verdade vos libertará, p. 203.

15 GS 26. 
aos pobres" (Lc 4,18). Em defesa de uma "Igreja dos pobres" e de uma opção pelos empobrecidos, o teólogo latino-americano, contra a crítica de uma politização da fé, nos diz que ver o rosto de Jesus naquele que sofre não é perder ou ferir a essência da mensagem cristã, nossa identidade eclesial. Não há perda de identidade, há sim "proveito dela". Conclui: "A identidade da Igreja consiste em estar do lado do Deus de Jesus Cristo, que ama qualquer pessoa e que tem predileção pelos últimos, pelos pobres. Não há perda de identidade quando neste contexto levamos em conta o que as colunas da Igreja pediram a Paulo: lembre-se dos pobres" (Gl 2,10). ${ }^{16}$

O Concílio Vaticano II teve um papel fundamental no desejo de recolocar uma vez mais a Igreja em diálogo com o mundo, atenta as dores e aos sofrimentos de tantos homens e mulheres, povos e culturas, que há muito tempo vivem à margem da sociedade. $\Lambda$ partir de um novo olhar hermenêutico, que vê no pobre a pessoa de Jesus e nos valores do mundo os antivalores do Reino, os padres conciliares abriram caminho para que cada realidade, cada continente, cada Conferência Episcopal, pudesse em seu contexto sócio eclesial pensar uma evangelização enraizada no compromisso e na transformação social. ${ }^{17}$

\section{O florescimento de uma nova tradição}

O Episcopado latino-americano, animado em colocar em prática as decisões do Vaticano II, marcou passo na história, quando após três anos do término do Concílio, realizou a segunda Conferência Episcopal latino-americana na cidade de Medellín (1968).

Medellín refaz, num certo sentido, o Vaticano II e, em muitos pontos dá um passo além: aí emerge pela primeira vez a importância das comunidades de base, esboça-se a teologia da libertação,

16 GUTIÉRREZ, G. A verdade vos libertará, p. 208.

${ }^{17} \quad L G 8$. aprofunda-se a noção de justiça e de paz ligadas aos problemas de dependência econômica e coloca-se o pobre no centro da reflexão do continente. ${ }^{18}$

Os bispos reunidos na Colômbia prosseguem a reflexão iniciada no Vaticano II levando adiante as proposições de seu grande incentivador, o Papa João XXIII, e dos padres conciliares vindos de todo o mundo. O Papa bom, através de suas encíclicas sociais, todo o trabalho de renovação eclesial realizado em cada seção conciliar, tocam de forma decisiva e comprometedora a Igreja da América Latina. No decorrer do Concílio, como vimos antes, surgiu uma corrente que colocava os pobres como centro da ação evangelizadora e por isso comprometia-se com eles, inclusive, a viver como eles. ${ }^{19}$ É, pois, nesta linha que se encontravam os bispos que participam de Medellín.

Conscientes da realidade do continente, os bispos reunidos em Medellín reconhecem que a Igreja não poderia ficar indiferente as injustiças sociais existentes na América Latina. O documento que traz as Conclusões de Medellín está carregado de uma profunda solidariedade para com o povo que sofre. Nele os bispos assumem que a Igreja da América Latina esteve letárgica e, por isso, sentem-se obrigados, como pastores, a dar voz aqueles que não a têm: "A pobreza de tantos irmãos clama por justiça, solidariedade, testemunho, compromisso, esforço e superação para o cumprimento pleno da missão salvífica confiada por Cristo". ${ }^{20}$

Seguindo as intuições e o profetismo de Medellín, a terceira Conferência do Episcopado latino-americano, reunida em Puebla

18 BEOZZO, José Oscar. A Igreja do Brasil: de João XXIII a João Paulo II, de Medellín a Santo Domingo, p. 117-118.

19 No dia 16/11/1965 cerca de 40 Padres Conciliares celebraram nas catacumbas de Domitila uma Eucaristia pedindo fidelidade ao Espírito de Jesus. Após essa celebração alguns deles firmaram o "Pacto das Catacumbas". Ver in: KLOPPENBURG Boaventura (org.). Concílio Vaticano II. Vol. V, Quarta Sessão. Petrópolis: Vozes 1966, 526-528.

$20 \quad D M 6$ 
(1979), se torna expoente desta opção em nosso continente, passando a utilizar a palavra "pobre” no sentido bíblico de anawin: o curvado, o oprimido. O termo tem, na Bíblia, uma conotação político-social. Designa o escravo, o estrangeiro, o perseguido, o cativo. Não se trata, pois do simples necessitado, mas do oprimido, do explorado. Não designa apenas o indivíduo, mas a classe social explorada, a raça marginalizada, o grupo oprimido.

Os números 31 a 49 do documento fazem um elenco dos pobres da América Latina: indígenas e afro-americanos, camponeses sem terra, operários, desempregados e sub-empregados, marginalizados e aglomerados urbanos, jovens frustrados socialmente e desorientados, crianças golpeadas pela pobreza, menores abandonados e carentes, a mulher. Em outros trechos, o documento se refere ainda aos migrantes e às prostitutas. Trata-se não da pobreza evangélica (disponibilidade para acolher a Deus e ao próximo com estilo de vida sóbria e honesta e liberdade existencial frente às riquezas), mas da pobreza anti-evangélica, que é sinônimo de exploração de opressão, de situação desumana. Trata-se da pobreza de dimensão sociopolítica, isto é, generalizada e estrutural. O documento é bem explícito: "Ao analisarmos mais a fundo tal situação, descobrimos que essa pobreza não é uma etapa transitória, e sim produto de situações e estruturas econômicas sociais e políticas que dão origem a esse estado de pobreza, embora haja também outras causas da miséria”. ${ }^{21}$

A opção pelo homem latino-americano, vilipendiado de tantas formas, busca abarcar a sua integridade, sua totalidade. O amor aos pobres naturalmente não é exclusivo, mas convida a todos os cristãos a lutar contra as estruturas de poder que fazem os pobres se tornarem cada vez mais pobres. No fundo, a Igreja latino-americana, com seus traços, rostos e culturas, nos "chama à esperança”,

${ }^{21} \quad D P 30-49$ ao acreditar em um novo mundo possível, mais justo e igualitário, mais fraterno e irmão. ${ }^{22}$ Sobre o caráter desta opção, frisa o texto:

A opção preferencial pelos pobres tem como objetivo o anúncio de Cristo Salvador, que os iluminará sobre a sua dignidade, os ajudará em seus esforços de libertação de todas as suas carências e os levava à comunhão com o Pai e os irmãos, mediante a vivência da pobreza evangélica. "Jesus Cristo veio para compartilhar nossa condição humana com seus sofrimentos, suas dificuldades, sua morte. Antes de transformar a existência cotidiana, ele soube falar ao coração dos pobres, libertá-los do pecado, abrir seus olhos para um horizonte de luz e enchê-los de alegria e esperança. Hoje, Jesus Cristo faz o mesmo. Está presente em vossas Igrejas, em vossas famílias, em vossos corações”. ${ }^{23}$

Muitos foram os frutos produzidos por esta opção fundamental e profundamente evangélica. Sacerdotes, consagrados e leigos foram impulsionados a chegar a lugares até então desconhecidos ou mesmo esquecidos pela Igreja como um todo, tais como: comunidades ribeirinhas e quilombolas, camponeses e trabalhadores rurais, moradores das regiões de periferia, operários e migrantes. Como podemos notar, a Igreja não excluiu ninguém, pelo contrário, demonstrou a partir de um trabalho silencioso, humilde e difícil, sua preferência pelos mais excluídos, pelos mais pobres. Essa opção não é apenas para uma parte da Igreja, da hierarquia, das pastorais e movimentos, ela deve ser fruto de um "processo de conversão" realizado por todos, no intuito de tornar realidade uma "libertação integral” dos que estão empobrecidos. ${ }^{24}$

Em continuidade com as Conferências de Medellín e de Puebla, a Igreja latino-americana reunida em Santo Domingo (1992) reafirmou a "opção preferencial pelos pobres". Uma opção como vimos,

\footnotetext{
$22 \quad D P 4$

23 DP 1153.

$24 \quad D P 733,1134$.
} 
não exclusiva nem excludente, pois a mensagem da salvação está destinada a todos, mas sensível aos mais vulneráveis. Contra todo tipo de ideologia, o documento destaca que esta opção está alicerçada na Palavra de Deus e não apenas em critérios retirados das ciências humanas, ou fruto da rivalidade entre grupos contrários entre si, que muitas vezes reduzem os pobres em "categorias sociopolíticas econômicas abstratas”. ${ }^{25}$

A partir desta compreensão é que se sustenta e solidifica a função profética da Igreja de anunciar primeiramente o Reino de Deus e a sua justiça (Mt 6,33). Livre dos “poderes deste mundo”, que escravizam e matam, fundamentada no Evangelho e em sua Doutrina Social, a Igreja encontra a "base necessária” e o "estimulo autêntico" para uma opção preferencial pelos pobres de modo concreto. Essa é a fundamentação que nos compromete "numa opção evangélica e preferencial pelos pobres”, “firme e irrevogável”, “tão solenemente afirmada nas Conferências de Medellín e Puebla”. Sob a luz desta “opção preferencial”, a exemplo de Jesus, "nos inspiramos para toda a ação evangelizadora comunitária e pessoal”. Com o "potencial evangelizador dos pobres" a "Igreja pobre" quer impulsionar a "evangelização de nossas comunidades”. ${ }^{26}$

Como síntese e ao mesmo tempo como reafirmação das opções realizadas pelo episcopado e pela Igreja latino-americana, a quinta Conferência realizada em Aparecida (2007) trouxe novamente à tona a preocupação com os pobres e excluídos de nosso continente. Partindo da ideia de “comunhão e participação”, o documento demonstra a importância do compromisso evangelizador e missionário entre os mais simples e afastados, pois, estes são a expressão visível de nossa “opção preferencial pelos pobres". ${ }^{27}$

\footnotetext{
${ }_{25} \quad D S D 16$.

${ }^{26}$ DSD 50, DP 1147, DSD 178.

$27 \quad D A p 179$
}

Dentro desta grande preocupação pela dignidade humana, situa-se, como nos recorda o texto "nossa angústia” pelos milhões de habitantes de nosso continente impedidos de levar uma vida que corresponda a essa dignidade, a mínimo necessário para sobreviver. A opção preferencial pelos pobres é uma das "peculiaridades" que marca a "fisionomia da Igreja latino-americana e caribenha". Reforça o documento:

Nossa fé proclama que "Jesus Cristo é o rosto humano de Deus e o rosto divino do homem”. Por isso, “a opcão preferencial pelos pobres está implícita na fé cristológica naquele Deus que se fez pobre por nós, para nos enriquecer com sua pobreza”. Essa opção nasce de nossa fé em Jesus Cristo, o Deus feito homem, que se fez nosso irmão (cf. Hb 2,11-12). Opção, no entanto, não exclusiva, nem excludente. ${ }^{28}$

Em um contexto marcado por inúmeras desigualdades e injustiças sociais, a Igreja latino-americana, naquilo que compõe sua tradição libertadora, soube levar a cabo, salvo alguns sinais de resistência, a renovação proposta pelo Concílio. Tamanha foi à importância deste momento na vida da Igreja, que ainda hoje não conseguimos colocar em prática muitas de suas intuições, proposições, chaves de leitura, hermenêuticas e interpretações. O sonho conciliar da "Igreja dos pobres" segue vivo, tornando-se realidade a partir da vida de tantos agentes de pastoral e comunidades que lutam ao lado dos pobres e contra a pobreza e todo tipo de exploração.

\section{Uma opção pelos pobres e contra a pobreza}

A opção pelos pobres tem despertado, a partir do Vaticano II e, de modo especial, a partir de Medellín e Puebla, intensa discussão envolta em muitas tensões, incompreensões e tentativas de amortecer suas implicações práticas. Sem dúvida, essa opção, nascida

$28 \quad$ DAp 391,392. 
na década de 1960, tem suas raízes na Bíblia. Na caminhada das comunidades eclesiais de base (CEBs), semelhante consciência está explicitada, por exemplo, no canto: “Javé, o Deus dos pobres, do povo sofredor, aqui nos reuniu pra cantar o seu louvor, pra nos dar esperança e contar com sua mão na construção do reino, reino novo, povo irmão”. Embalado pela canção, enfatiza o teólogo:

O livro do Êxodo mostra um Deus que age na história como libertador: "Eu vi, eu vi a miséria do meu povo que está no Egito. Ouvi seu grito por causa de seus opressores; pois eu conheço as suas angústias. Por isso desci a fim de libertá-lo da mão dos egípcios e para fazê-lo subir desta terra para uma terra boa e vasta, terra que mana leite e mel" (Ex 3,7-8b). Essa tradição do Deus libertador se expressa na profissão de fé do povo libertado: "Eu sou Iahweh teu Deus que te fez sair da terra do Egito, da casa da escravidão” (Ex 20,2). É por tal razão que Gustavo Gutiérrez a chama de opção teocêntrica. ${ }^{29}$

Refletindo sobre o que compõe a opção pelos pobres, Padre Beni no diz que: "Opção" quer dizer decisão, tomada de partido. Entre opressores e oprimidos (no caso latino-americano), a Igreja toma o partido dos últimos. Trata-se de uma decisão política (pois os pobres são fruto de uma estrutura sociopolítica opressora), ética (é um imperativo moral) e evangélica (pois essa foi à opção de Jesus). A opção pelos pobres implica uma mudança de lugar social. $O$ lugar social condiciona o nosso discernimento: sensibilidade para perceber, leitura da realidade, decisão. Se estamos, por exemplo, no lugar social do poder do privilégio, então a nossa leitura da realidade dificilmente se fará fora da perspectiva funcionalista. Iremos sem dúvida, privilegiar determinados valores como ordem, harmonia,

\footnotetext{
29 FERRARO, Benedito. Opção pelos pobres no Documento de Aparecida, p. 10-14.
}

tranquilidade. Nossa ação provavelmente se desenvolverá numa linha assistencialista. ${ }^{30}$

A própria leitura das Escrituras privilegiará os temas, os textos e os contextos, que justificam a visão funcionalista da Igreja e do mundo. No caso da Igreja, por exemplo, correremos o perigo de conceber a sua unidade de modo meramente vertical, isto é, uma unidade restrita ao dogma, à moral, à obediência aos legítimos pastores; uma unidade para cima e não para os lados também, isto é, unidade que implica comunhão de bens, questionamento da escandalosa presença de opressores e oprimidos na celebração da mesma eucaristia.

Qualquer plano de pastoral supõe, como ponto de partida, o questionamento sobre o lugar social daqueles que vão elaborá-1o. A opção preferencial pelos pobres é, no documento, o ângulo, através do qual os bispos fazem a leitura da realidade latino-americana, abrem pistas, questionam, denunciam e anunciam. Esse ângulo leva-nos a sublinhar algumas dimensões da cristologia, eclesiologia e evangelização, muito relevantes para a situação sócio-política do nosso continente. Uma opção preferencial. ${ }^{31}$

A partir do lugar social dos pobres, portanto, a partir de baixo, a Igreja procura evangelizar a todos. Convida todos a uma conversão que implica em abraçar a causa dos pobres. É a partir deles e através do seu dinamismo libertador, que a Igreja procura compreender o mistério do Reino (Mt 11,25) para anunciá-lo ao mundo inteiro. Se existe nos pobres um potencial evangelizador, então podemos afirmar que, na América Latina, uma parte da Igreja (hierarquia, religiosos, elites leigas) está sendo evangelizada pela outra parte (o povo pobre) através, principalmente, da interpelação

\footnotetext{
30 SANTOS, Padre Beni. Introdução a uma leitura do Documento (Puebla) a partir da opção preferencial pelos pobres.
}

31 Ibidem. 
e do questionamento, que conduzem à conversão, à solidariedade, à simplicidade, ao serviço. ${ }^{32}$

A opção pelos pobres significa, em última instância, uma opção pelo Deus do reino que Jesus nos anuncia. Toda a Bíblia, desde o relato de Caim e Abel, está marcada pelo amor de predileção de Deus pelos fracos e maltratados da história humana. É isso que nos revelam as bem-aventuranças evangélicas: elas nos afirmam, com profunda simplicidade, que a predileção pelos pobres, famintos e sofredores tem seu fundamento na bondade gratuita do Senhor. O motivo último do compromisso com os pobres e oprimidos não está na análise social que empregamos, em nossa compaixão humana ou na experiência direta que podemos ter da pobreza. Todas estas são razões válidas que jogam, sem dúvida, um papel importante em nosso compromisso, mas, como cristãos, ele se embasa fundamentalmente no Deus de nossa fé. É uma "opção teocêntrica" e "profética" que lança suas raízes na gratuidade do amor de Deus. ${ }^{33}$

A Igreja dos pobres na América Latina não nasce somente de um esforço acadêmico. Ela nasce, primeiramente, da experiência do povo que sofre. Mesmo sem a ideia de teologia o povo latino-americano se recusa a entregar-se a uma estrutura de morte, por isso, emergem dele várias práticas libertadoras. Somente a partir desta prática é que a Igreja se vê impulsionada a fazer uma reflexão eclesiológica. Essa reflexão é caracterizada como o ato segundo, pois o ato primeiro é práxis, uma reflexão crítica à luz do Evangelho sobre a vida e a prática cristã eclesial, abre-se neste contexto uma nova forma de anunciar o querigma. ${ }^{34}$

Formado em nossa tradição libertadora e sensível ao sofrimento humano, especialmente dos pobres e marginalizados, Francisco, em seu pontificado, tem apontado para Igreja a partir de sua vida e

32 Ibidem.

33 GUTiÉRREZ, G. "Pobres y opción fundamental”, p. 309.

34 GUTIÉRREZ, G. A verdade vos libertará, p. 18 de seus gestos a intrínseca relação entre evangelização e promoção social, entre Igreja e mundo, teologia e sociedade. O Papa que "veio do fim do mundo”, palavras suas usadas minutos após a sua eleição, em seu projeto de renovação eclesial, alinhado com as proposições conciliares, convida toda a Igreja a redescobrir e a experimentar a “alegria do Evangelho”, a alegria de sermos missionários, como nos interpela o próprio Cristo: "O Espírito do Senhor é sobre mim, Pois que me ungiu para evangelizar os pobres” (Lc 4,18).

\section{Um papa latino-americano}

O pontificado de Francisco tem se mostrado como uma nova primavera na vida da Igreja. O primeiro papa latino-americano leva consigo o frescor de uma vivência eclesial viva e dinâmica, próprias de nosso continente, uma cultura rica em expressões, ritmos e cores, além de todo nosso histórico de lutas, compromisso social, defesa dos empobrecidos, comunidades de base, mística e espiritualidade.

Publicada em 2013, a Exortação Apostólica Evangelii Gaudium foi entendida como a "carta de princípios" na aurora de um novo pontificado, com um significado programático e com consequências importantes para toda a Igreja. O documento é fruto da $13^{a}$ Assembleia Geral Ordinária do Sínodo dos Bispos sobre "a nova evangelização para a transmissão da fé cristã, que reuniu 170 bispos do mundo inteiro em Roma em outubro de 2012”. Tão significativa foi a sua recepção e profundidade, que, para Suess, a partir deste documento “o magistério latino-americano, de modo particular a Conferência de Aparecida”, na qual Francisco deu a sua colaboração, "tornou-se magistério universal da Igreja Católica”. ${ }^{35}$

Francisco levou à Cátedra de Pedro em Roma a experiência da Igreja latino-americana a partir do modo como viveu, rezou, refletiu e fez pastoral. Na percepção de Ortiz, na mesma direção de Suess, o

35 SUESS, P. Dicionário da Evangelii Gaudium, p. 8-9. 
papa universalizou o espírito de Aparecida para toda a Igreja ao escrever sua Exortação sobre a alegria de evangelizar. Quando olhamos para seu pontificado, segundo o teólogo, percebemos um constante apelo, especialmente a partir de seus gestos, para uma conversão pastoral, que nada mais é do que uma pastoral missionária, "em saída”, comprometida com os pobres e excluídos, que promova 0 encontro com Jesus, sua Palavra, a proposta do seu Reino. ${ }^{36}$

A compreensão hermenêutica e a proposta de "uma Igreja pobre e para os pobres” estão no centro das preocupações e orientações pastorais de Francisco e são a marca evangélica mais característica de seu ministério petrino. É o que o vincula de modo mais visível e radical à Boa Notícia do reinado de Deus, centro da vida e missão de Jesus de Nazaré. ${ }^{37}$ Francisco garante de modo claro e contundente, que "para a Igreja, a opção pelos pobres é mais uma categoria teológica que cultural, sociológica, política ou filosófica”. "No coração de Deus, ocupam lugar preferencial os pobres" e "esta preferência divina tem consequências na vida de fé de todos os cristãos" ${ }^{38}$

Para Paulino, na medida em que Francisco em sua Exortação vai percorrendo vários textos da Escritura e a reflexão da Igreja ao longo dos séculos, particularmente nas últimas décadas, vai mostrando como "todo o caminho da nossa redenção está assinalado pelos pobres” ${ }^{39}$ e insistindo, desde então, na “conexão íntima que existe entre evangelização e promoção humana”, ${ }^{40}$ bem como no primado ou privilégio dos pobres na ação evangelizadora da Igreja: "Não devem subsistir dúvidas nem explicações que debilitem esta mensagem claríssima. Hoje e sempre, 'os pobres são os destinatários privilegiados do Evangelho', e a evangelização dirigida gratuitamente

\footnotetext{
${ }^{36}$ ORTIZ, G. El Papa encarna y pone en acto Aparecida y Evangelii Gaudium

37 PAULINO, F. A. Uma Igreja pobre e para os pobres, p. 47.

$38 \quad E G$ 197, 198

$39 \quad E G 197$.

${ }^{40} \quad E G 178$
}

a eles é sinal do Reino que Jesus veio trazer. Há que afirmar sem rodeios que existe um vínculo indissolúvel entre nossa fé e os pobres”. ${ }^{41}$ Ficar "surdo" ao clamor dos pobres "coloca-nos fora da vontade do Pai e do seu projeto"; "a falta de solidariedade, nas suas necessidades, influi diretamente sobre nossa relação com Deus”. ${ }^{42}$ E nisso não há dúvidas, titubeio ou meias palavras. Destaca o teólogo: “A opção pelos pobres pertence ao coração do Evangelho do reinado de Deus e, enquanto tal, ela é constitutiva (e não meramente consecutiva e opcional!) da fé cristã”, ${ }^{43}$

Francisco indica, com apoio em sua experiência pastoral, alguns aspectos ou exigências da opção pelos pobres que bem podem ser entendidos como uma pedagogia ou um itinerário no compromisso com os pobres e que, no fundo, revelam sua compreensão e seu modo de viver tal opção.

Em primeiro lugar, existe a proximidade física dos pobres e o esforço por socorrê-los em suas necessidades imediatas. É preciso escutar o "clamor do pobre" e estar disposto a "socorrê-lo". Em segundo, o "cuidado espiritual" com os pobres. "A imensa maioria dos pobres possui uma especial abertura à fé”; tem necessidade de Deus e não podemos deixar de lhes oferecer a sua amizade, a sua bênção, a sua Palavra; a celebração dos sacramentos e a proposta de um caminho de crescimento e amadurecimento na fé. Em terceiro, está à vivência e o fortalecimento de uma cultura da solidariedade. Isso "significa muito mais do que alguns atos esporádicos de generosidade; supõe a criação de uma nova mentalidade que pense em termos de comunidade, de prioridade da vida de todos sobre a apropriação dos bens por parte de alguns”. Em quarto, o enfrentamento das causas estruturais da pobreza e da injustiça no mundo. "Embora 'a

\footnotetext{
$41 \quad E G 48$.

$42 \quad E G 187$

43 PAULINO, F. A. Uma Igreja pobre e para os pobres, p. 48
} 
justa ordem da sociedade e do Estado seja dever central da política’, a Igreja 'não pode nem deve ficar à margem na luta pela justiça". ${ }^{4}$

A “Igreja pobre para os pobres” do Papa Francisco é, consequentemente, um princípio norteador que orienta e qualifica, no sentido evangélico, a escolha da pobreza e o serviço aos pobres, continuando assim a maravilhosa história da caridade da Igreja, que ao longo dos séculos sempre foi instrumento de libertação, inclusão, e promoção dos pobres, tendo a perspectiva da liberdade e do amor de Cristo. Ele não só oferece uma solidariedade concreta, estável e generosa, mas está ativamente encarregado, também para afirmar a dignidade da pessoa, da busca pela justiça, a fim de construir uma civilização em que todos têm o direito de serem chamados de "humanos". ${ }^{45}$

A evangelização tem uma dimensão social: evangelizar é tornar presente o Reino de Deus, começando pelos prediletos do Senhor, os pobres, hoje reduzidos a "seres descartáveis", a multidões consideradas como "restos". Vale a pena reforçar uma vez mais que a opção pelos pobres que estamos refletindo não é cultural, nem sociológica, nem política, como argumentam os defensores de alas mais conservadoras da Igreja, querendo com isso desviar o foco da mensagem cristã e permanecerem em sua zona de conforto. A opção pelos pobres, inspirada em Jesus de Nazaré é antes de tudo, uma opção evangélica, bíblica e teológica. Os pobres, a sua piedade religiosa, constituem um verdadeiro "lugar teológico", um "lugar" onde compreendemos o cerne da mensagem cristã, onde somos evangelizados. ${ }^{46}$

Para Moliner, falar do pobre como "lugar teológico", implica também ver em cada um deles uma nova manifestação da cruz, e assim como esta, a pobreza, então, revela porque desinstala. Isto é, diante do sofrimento das vítimas, o ser humano reage com

$44 \quad E G$ 183, 187, 188, 200.

45 FRANCISCO. A Igreja da Misericórdia, p. 9.

$46 \quad E G$ 176, 195, 198. misericórdia: sai de si mesmo e se rebela para erradicar esse sofrimento. Por isso, em suas palavras e em consonância como o pensamento de Francisco, nos diz: "para descobrir os pobres como lugar teológico, há de optar por eles e assumir sua causa”. ${ }^{47}$

O sonho de João XXIII ao começar o Concílio Vaticano II, a opção preferencial pelos pobres da Igreja latino-americana em Medellín e Puebla, a afirmação de Bento XVI de que "a opção pelos pobres” está implícita na nossa fé cristológica, as afirmações do Documento de Aparecida de que não se pode falar de Deus sem falar dos pobres, ${ }^{48}$ prolongam-se no desejo de Francisco de uma Igreja pobre e para os pobres. ${ }^{49}$ Neste sentido, o Papa vindo do terceiro mundo, parece não deixar de lado as discussões que o tema tem suscitado na Igreja nas últimas décadas, ao repetir: "ninguém pode sentir-se exonerado da preocupação pelos pobres e pela justiça social”. ${ }^{50}$

Aqui se encontra, inevitavelmente, na visão eclesial e pastoral de Francisco, a sua idéia sobre o homem e a sociedade. O seu é um discurso articulado, paralelo, mas que interage com o resto; um discurso direto e forte, que abala a consciência para atingir o coração "endurecido" de uma sociedade fechada para a cultura do encontro e do bem, condições necessárias da fraternidade, da paz e do viver. Até que sejam derrubados os ídolos chamados de: poder, dinheiro, corrupção, carreirismo, egoísmo, indiferença e, resumidamente "o espírito do mundo”, é impossível continuar na direção desejada de um mundo melhor. ${ }^{51}$

Contra todo tipo de preconceito, discriminação e atitude de fechamento aos pobres e excluídos, em uma de suas catequeses, enfatiza o Bispo de Roma:

\footnotetext{
47 MOLINER, A. Pluralismo religioso e sofrimento eco-humano, p. 47

48 DAP 393.

$49 \quad E G 197$.

50 GONZÁlEZ-QUEVEDO, L. Para uma Igreja mais saudável, p. 59

$51 \quad$ FRANCISCO. A Igreja da Misericórdia, p. 9.
} 
Quantas vezes encontramos um pobre e, mesmo sendo generosos e sentindo compaixão, não o tocamos. Oferecemos uma moeda, mas evitamos tocar sua mão. Esquecemos que aquele é o corpo de Cristo! Jesus nos ensina a não ter medo de tocar o pobre e o excluído, porque Ele está neles. Tocar o pobre pode nos purificar da hipocrisia e nos preocupar por sua exclusão. ${ }^{52}$

A compreensão hermenêutica de que Deus ama os pobres porque se fez pobre também (Fl 2,6-8) é fundamental para que não deixemos de estar ao lado dos pobres em sua busca por dignidade e inclusão social. A luta não pode parar! Como nos recorda Dom Hélder: "não deixemos morrer a profecia", o compromisso social.

\section{Considerações finais}

Ao chegarmos ao final de nosso percurso podemos constatar quão significativa foi à convocação e a realização do Concílio Vaticano II. Uma Igreja, que até então estava em choque com as proposições e caminhos do mundo moderno, se abriu ao diálogo e a um profundo processo de renovação eclesial. Questões que foram colocadas em segundo plano, tais como, os avanços científicos e tecnológicos, o ecumenismo, o diálogo inter-religioso e a preocupação com a dimensão social da evangelização, ganharam um novo fôlego. Desvencilhando-se do método dedutivo, a teologia neste novo contexto vê na indução a oportunidade de confrontar os dados da Revelação e as verdades da fé com a vida, com a existência, com o mundo e a história, possibilitando assim, novas hermenêuticas, novas leituras, novos voos.

As intuições e proposições conciliares foram recebidas com muito entusiasmo pelo CELAM, que a partir da Conferência de Medellín (1968) muitos bispos e teólogos latino-americanos começaram pensar uma nova evangelização em um continente marcado por injustiças sociais, ditaduras, mortes e um crescente número de pobres

52 FRANCISCO, "Não tenham medo de tocar o pobre e o excluído". e miseráveis. A opção preferencial pelos pobres nasce neste contexto como uma resposta bíblica, evangélica, cristológica e teocêntrica visando uma resposta, uma atitude profética, um novo jeito de ser Igreja que não compactua ou se cala diante do sofrimento humano. Assumida por décadas em toda Igreja latino-americana, esta opção foi sendo aos poucos eclipsada por um projeto de renovação desencadeado no pontificado de João Paulo II tendo a sua derrocada no pontificado de Bento XVI. Com a eleição de Francisco a renovação eclesial iniciada pelo Concílio retomou o seu curso e a preocupação com os pobres e marginalizados ganhou novamente uma notória evidência.

Nesta perspectiva a Evangelii Gaudium, refletindo sobre o anúncio do Evangelho no mundo atual, coloca em lugar de destaque a dimensão social da evangelização, a transformação do mundo, da sociedade e da Igreja pela alegria do Evangelho. Para Francisco evangelizar é tornar o Reino de Deus presente, especialmente para os pobres a quem Deus tem a sua predileção (Tg 2,5), muitas vezes privados do banquete da vida em uma sociedade que os vê como "descartáveis", marcada pelo individualismo, pelo acúmulo de bens e pela busca desenfreada por poder e riquezas. Para o Bispo de Roma, como Igreja que caminha nas estradas de Jesus, devemos escutar, socorrer, cuidar dos crucificados do tempo presente. Em sua compreensão isso será possível a partir de uma mudança de mentalidade, de lugar social, pois, não basta falar dos pobres se não em meio a eles, a partir de um profundo processo de conversão pessoal e comunitária, onde ninguém se sinta mais exonerado de sua responsabilidade e participação na mudança das estruturas, eclesiais e religiosas.

Em síntese, a teologia em sua tarefa hermenêutica, à medida que se conecta com os desafios do tempo presente, que busca compreender as novas linguagens, a apropriação e a assimilação do Sagrado por parte das pessoas e das culturas, oferece como um serviço à possibilidade da Igreja pensando-se a si mesma e as suas estruturas, renovar-se constantemente em vista de uma maior 
fidelidade ao Evangelho, aberta ao diálogo com o mundo, capaz de ler os sinais dos tempos. Contemplando a Evangelii Gaudium é nitidamente perceptível a importância dos pobres como uma de suas chaves interpretativas. Contudo, a opção pelos pobres, tão presente e preciosa em sua primeira exortação, nos faz pensar que ela também pode ser considerada como uma chave hermenêutica de todo o seu pontificado. O programa de uma "Igreja pobre" para ser definitivamente a "Igreja dos pobres".

\section{Bibliografia}

BEOZZO, José Oscar. A Igreja do Brasil: de João XXIII a João Paulo II, de Medellín a Santo Domingo. Petrópolis: Vozes, 1993.

BÍBLIA. Português. A Bíblia. Tradução Ecumênica. São Paulo: Loyola/ Paulinas, 1995.

BOFF, Clodovis. O livro do sentido: crise e busca de sentido hoje (parte crítico-analítica), volume I. São Paulo: Paulus, 2014.

BRIGHENTI, A. A Igreja perplexa: a novas perguntas, novas respostas. São Paulo: Paulinas, 2004.

CONCÍLIO VATICANO II. Compêndio do Vaticano II: Constituições, decretos e declarações. Petrópolis: Vozes, 1968.

FERRARO, Benedito. Opção pelos pobres no Documento de Aparecida. Revista Vida Pastoral. São Paulo: Paulus, n. 257, 2007, p. 10-14.

FRANCISCO. A Igreja da Misericórdia: minha visão para a Igreja. Organização: Giuliano Vigini. São Paulo: Paralela, 2014, 1 ed.

FRANCISCO. Evangelii Gaudium: Exortação Apostólica do Sumo Pontífice ao episcopado, ao clero, às pessoas consagradas e aos fiéis leigos sobre o anúncio do Evangelho no mundo atual. São Paulo: Paulus, 2013.

FRANCISCO. "Não tenham medo de tocar o pobre e o excluído". Rádio Vaticano. 22 jun, 2016. Disponível em: <http://br.radiovaticana.va/ news/2016/06/22/papa_n\%C3\%A3o_tenham_medo_de_tocar_o_pobre e exclu\%C3\%ADdo/1239019> Acesso em: 04 dez. 2016

GONZÁLEZ-QUEVEDO, L. Para uma Igreja mais saudável: sugestões ao Papa Francisco. Revista Eclesiástica Brasileira, Petrópolis, vol. 75, n. 297, p. 45-70, jan./mar. 2015
GUTIÉRREZ, G. A verdade vos libertará: confrontos. São Paulo: Loyola, 2000.

GUTIÉRREZ, G. “Pobres y opción fundamental”, in: I. Ellacuría; J. Sobrino (eds.) Mysterium liberationis: conceptos fundamentales de la teología de La liberación. San Salvador: UCA, tomo I, 1991, p. 309.

JOÃO XXIII. Radiomensaje de su santidad Juan XXIII un mes antes de la apertura del Concilio Vaticano II (Martes 11 de septiembre de 1962) Vaticano: Libreria Editrice Vaticana, 1962.

KLOPPENBURG, Boaventura (org.). Concílio Vaticano II. Vol. V, Quarta Sessão. Petrópolis: Vozes, 1966

KÖRTNER, Ulrich H. J. Introdução à hermenêutica teológica. São Leopoldo: Sinodal/EST, 2009.

LERCARO, G. Per la forza dello Spirito: Discorsi conciliari. Bologna: Edizioni Dehoniane, 1984.

LIBANIO, J.B.; MURAD, A. Introdução à teologia: perfil, enfoques, tarefas. São Paulo: Loyola, 2007, 6 ed.

MOLINER, A. Pluralismo religioso e sofrimento eco-humano: a contribuição de Paul F. Knitter para o diálogo inter-religioso. São Paulo: Paulinas, 2011.

ORTIZ, G. El Papa encarna y pone en acto Aparecida y Evangelii Gaudium. Radio Vaticano. 06 jul, 2015. Disponível em: < http://es.radiovaticana. va/news/2015/09/14/el_papa_encarna_y_pone_en_acto_aparecida_y_ evangelii_gaudium/1156402> Acesso em: 02 dez. 2015

PAULINO, F. A. Uma Igreja pobre e para os pobres: abordagem teológico-pastoral. Kairós: Revista Acadêmica da Prainha, Fortaleza, v. 10 n. 1, p. 35-56, 2013

SANTOS, Padre Beni. Introdução a uma leitura do Documento (Puebla) a partir da opção preferencial pelos pobres. SBC. 2012. Disponíve em: http://www.infosbc.org.br/portal/index.php/legislacao-canonica/ 2704-documento-de-puebla. Acesso em: 27 ago, 2016.

SUESS, P. Dicionário da Evangelii Gaudium: 50 palavras-chave para uma leitura pastoral. São Paulo: Paulus, 2015.

Recebido em: 25/01/2017

Aprovado em: 29/05/2017 